\title{
An English Version of the Mathematics Teaching Anxiety Scale
}

\author{
Thomas E. Hunt (id $1{ }^{*}$, Mehmet Hayri Sari (id 2 \\ ${ }^{1}$ University of Derby, School of Human Sciences, University of Derby, UK. \\ ${ }^{2}$ Nevşehir Hacı Bektaş Veli University, Faculty of Education, Turkey.
}

\section{ARTICLE HISTORY}

Received: 10 May 2019

Revised: 08 August 2019

Accepted: 21 August 2019

\section{KEYWORDS}

Mathematics,

Teaching,

Anxiety,

Scale,

MTAS

\begin{abstract}
This study represents the implementation of an English version of the Mathematics Teaching Anxiety Scale (MTAS), originally published in Turkey (Sari, 2014). One hundred and twenty-seven primary school teachers from across the U.K. completed the survey, including 74 qualified teachers and 53 trainees. Following item-reduction and factor analysis, the 19-item MTAS was found to have excellent internal consistency $(\alpha=.94)$ and has a two-factor structure. Factor one, labelled Self-Directed Mathematics Teaching Anxiety, includes 12 items pertaining to a teacher's own teaching practice and perceived ability, whereas factor two, labelled Pupil/Student-Directed Mathematics Teaching Anxiety, includes 7 items pertaining to anxiety concerning pupils/students failing assessments or not reaching curriculum/school targets. Pre-service teachers, compared to inservice teachers, self-reported significantly higher overall maths teaching anxiety. Among in-service teachers, there was a significant negative correlation between length of service and maths teaching anxiety. These findings are important in the context of retention issues in newly qualified teachers and the need to support trainees and newer teachers if they experience anxiety related to teaching maths.
\end{abstract}

\section{INTRODUCTION}

Mathematics anxiety is a pervasive issue that appears to exist across a range of populations (Hembree, 1990; OECD, 2013) and can be defined as "feelings of tension and anxiety that interfere with the manipulation of numbers and the solving of mathematical problems in a wide variety of ordinary life and academic situations" (Richardson \& Suinn, 1972, p. 551). Empirically measuring anxiety pertaining to numbers began in 1958 with the Numerical Anxiety Scale (Dreger \& Aiken, 1957). Since then several self-report scales for measuring maths anxiety have been published (e.g. Richardson \& Suinn, 1972; Sandman, 1979; Betz, 1978; Plake \& Parker, 1982, Hunt, Clark-Carter \& Sheffield, 2011). However, these have been developed for use in a general population without much concern for specific contexts or populations. For example, Baloglu and Kocak (2006) observed that students who majored in elementary (primary) education were amongst the most maths anxious in over seven hundred U.S. university students. This echoes earlier observations that pre-service (student) elementary teachers are especially prone to maths anxiety (Hembree, 1990). As such, it may be necessary to focus on specific populations, e.g. teachers and pre-service teachers. A strong relationship

CONTACT: Thomas E. Hunt $\square$ t.hunt@derby.ac.uk $\equiv$ University of Derby, School of Human Sciences, University of Derby, UK 
has been demonstrated between maths anxiety and confidence in teaching maths among preservice teachers (Bursal \& Paznokas, 2006). In an attempt to reduce maths anxiety in female pre-service teachers, Lake and Kelly (2014) observed little change after completion of an early childhood mathematics course; the authors suggest this is indicative of the students' entrenched beliefs about maths and their ability to do maths. It may also be important to draw a distinction between teachers' and pre-service teachers' maths anxiety and their level of anxiety towards teaching maths. Hadley and Dorward (2011) studied these variables in a large sample $(\mathrm{N}=692)$ of elementary school teachers in the U.S. and found a significant, moderate, positive correlation.

Research on maths anxiety in teachers and pre-service teachers is limited, with only a small amount of work having been conducted in the U.K. One study (Jackson, 2008) investigated 31 British student primary school teachers and found only $19 \%$ experienced no negative emotional or physical factors when engaged in maths. Jackson also observed that the students had somewhat negative perceptions of maths and $68 \%$ indicated a lack of confidence in teaching maths. Relatedly, Isiksal, Curran, Koc and Askun (2009) found a significant negative relationship between maths anxiety and maths self-concept among trainee teachers in the U.S. and Turkey. In a qualitative investigation, Trujillo and Hadfield (1999) interviewed six highly maths anxious pre-service elementary school teachers in the U.S. and analysis revealed several commonalities amongst the pre-service teachers in relation to their negative emotions pertaining to maths. For example, participants shared negative experiences of maths at school, referring to pressure, poor teaching and humiliation. Similarly, they shared negative experiences of maths within the family, typically referring to unsupportive parents. Shared experiences also extended to magnified anxiety in maths test situations, for example, referring to the maths component of teaching qualification tests. Interestingly, participants expressed a range of attitudes towards teaching maths themselves, seemingly taking into consideration their own negative experiences when planning their lessons; they emphasised previously or currently worrying about preparation and generally advocated a more progressive approach to teaching maths. It may be necessary to consider a range of demographic or individual differences, though. For example, in a further study of pre-service elementary school teachers, Hadfield and McNeil (1994) found a significant positive correlation between age and maths anxiety, such that older participants experienced greater maths anxiety. The authors suggest this may be associated with a lack of confidence in returning students, perhaps due to feeling "rusty" or having a poor background in maths. Providing some support for this argument, Isiksal et al. (2009) found pre-service teachers in the U.S to report significantly higher maths anxiety than pre-service teachers in Turkey, with the authors suggesting the difference might be explained by higher levels of maths familiarity and academic preparedness among Turkish pre-service teachers. Length of time in service may act as a buffer against maths anxiety though, with Gresham (2018) observing a significant reduction in self-reported maths anxiety among ten inservice elementary school teachers five years into teaching.

Interestingly, research findings have indicated it is anxiety towards teaching maths that predicts the adoption of a more traditional teaching style (Hadley \& Dorward, 2011). Similarly, Sari and Aksoy (2016) found a negative relationship between maths teaching anxiety and teaching style in Turkey; primary school teachers were found to shift from student-centred teaching to teachercentred teaching when their mathematics teaching anxiety increased. However, recognised scales that have been developed to specifically test maths teaching anxiety are limited. One scale, the Mathematics Teaching Anxiety Scale (MTAS) (Sari, 2014), was originally developed using a Turkish population of elementary school teachers, although the extent and nature of maths teaching anxiety in the U.K. is unknown. As such, a study using an English version of the MTAS would provide some much needed information, particularly in the context of a poor retention rate of early-career teachers in science, maths and languages (Worth \& De Lazzari, 2017) and the need to better understand the reasons for this. Understanding anxiety pertaining 
to the teaching of maths may also support further research concerning transference of anxiety to students as well as its relationship with teaching style.

\section{METHOD}

A cross-sectional approach was taken in which an online survey was provided to primary school teachers across the United Kingdom via opportunity sampling.

\subsection{Participants}

Teachers were required to have (or be working towards) qualified teacher status (QTS). One hundred and twenty-seven participants provided full data, which included $102(80.30 \%)$ females and 25 (19.7\%) males. Participant ages ranged from 18 to 69 years $(\mathrm{M}=33.57, \mathrm{SD}=$ $12.31)$ and the sample included $74(58.30 \%)$ qualified teachers (mean age $=40.93$ years, $\mathrm{SD}=$ 9.96; mean teaching years $=14.97, \mathrm{SD}=9.69)$ and $53(41.70 \%)$ trainees (mean age $=23.30$ years, $\mathrm{SD}=6.57$ ).

\subsection{Data Collection Techniques}

The Mathematics Teaching Anxiety Scale (MTAS) was originally developed using a Turkish population of elementary (primary) school teachers. The MTAS was published in 2014 and contains 23 items. It has high internal consistency $(\alpha=.89)$ and original analyses indicated a three-factor structure (Sari, 2014): i) anxiety regarding maths teaching processes, ii) anxiety regarding maths content knowledge, and iii) anxiety related to maths self-efficacy. The scale lists a range of statements pertaining to different aspects of maths teaching and requires participants to respond on a Likert-type scale regarding how frequently they experience the content of each statement. The response format has five points and ranges from "always" to "never", with higher scores representing lower anxiety (thus requiring reversing upon data analysis). The scale was originally published in Turkish, so a process of forwards-backwards translation took place, involving multiple academic colleagues, to arrive at an English version of the scale.

\subsection{Data Collection Procedure}

The survey was administered using Qualtrics online survey software and was advertised via email and social media. Demographic questions were presented first, followed by the maths teaching anxiety measure. Ethical considerations were consistent with the guidelines proposed by the British Psychological Society.

\subsection{Data Analysis}

The standard procedure was followed, in which internal consistency of the scale and scale items was assessed, followed by an exploratory factor analysis and scale refinement. Group comparisons were made on the teacher variables of sex and teaching status.

\section{RESULTS}

\subsection{Internal consistency - stage 1}

The minimum item-total correlation was .42, with a mean of .66. Cronbach's alpha was 944 and no items were suggested for removal. A Kolmogorov-Smirnov test indicated total scale scores to be significantly positively skewed $(\mathrm{p}<.001)$; however, inspection of the histogram indicated only slight positive skew.

\subsection{Exploratory factor analysis}

As the study represents the first administration of an English version of the MTAS, an exploratory factor analysis was conducted. A high Kaiser-Meyer-Olkin measure (KMO = .911) indicated that sampling adequacy was met and low values in the diagonal of the anti-image 
correlation matrix provided further evidence that the data were suitable for factor analysis (Tabachnick \& Fidell, 2001). The mean correlation between extracted factors, based on eigenvalues above one, was <.1, thus indicating independence of factors and therefore verifying the decision to use a varimax rotation. Initially, using eigenvalues above one as criteria for factor extraction, four factors were extracted. The four factors explained a total of $66.56 \%$ of the variance, with $46.21 \%, 10.47 \%, 5.10 \%$, and $4.74 \%$ of the total variance, being explained by factors one to four respectively. The rotated factor matrix revealed several items that did not load sufficiently on to a single factor. In addition, observation of the scree plot indicated the existence of two factors. As such, a further factor analysis was performed in which a two-factor solution was forced. This revealed a much more parsimonious structure in which every item had a factor loading of at least .4. The two factors explained a total of $56.73 \%$ of the variance, with $46.26 \%, 10.47 \%$ of the total variance, being explained by factors one and two respectively. Four items were removed due to cross-factor loading. Cronbach's alpha for the resultant 19item MTAS was .93.

\subsection{Factor Labelling}

The two factors appeared to represent very distinct underlying constructs pertaining to maths teaching anxiety. In addition to the authors, four independent academics working in the field of maths education were consulted to interpret the nature of factors that the items represent. There was consensus in interpretations. Factor one contained 12 items that relate to a teacher's own teaching practice and perceived maths ability, e.g. "I avoid talking about mathematics teaching with other teachers outside the classroom" and "I worry that I won't be able to answer a question whilst teaching a maths class". Therefore, factor one was labelled Self-Directed Mathematics Teaching Anxiety. Factor two comprised 7 items that relate to teachers' anxiety concerning their pupils, e.g. "The thought that students/pupils will not meet curriculum/school targets in maths worries me" and "I worry that students/pupils in my maths class will fail their assessments". Thus, factor two was labelled Pupil/Student-Directed Mathematics Teaching Anxiety.

\subsection{Group comparisons}

There was no significant difference between males and females in overall mathematics teaching anxiety, $\mathrm{t}(125)=1.27, \mathrm{p}=.21, \mathrm{~d}=0.28$, self-directed mathematics teaching anxiety, $\mathrm{t}(125)=$ $1.45, \mathrm{p}=.15, \mathrm{~d}=0.35$, or pupil/student-directed mathematics teaching anxiety, $\mathrm{t}(125)=0.42$, $\mathrm{p}=.68, \mathrm{~d}=0.09$. However, pre-service teachers, compared to in-service teachers, self-reported significantly higher overall maths teaching anxiety, $\mathrm{t}(125)=5.78, \mathrm{p}<.001, \mathrm{~d}=1.07$, selfdirected mathematics teaching anxiety, $\mathrm{t}(125)=6.59, \mathrm{p}<001, \mathrm{~d}=1.18$, and pupil/studentdirected mathematics teaching anxiety, $\mathrm{t}(125)=2.12, \mathrm{p}=.04, \mathrm{~d}=0.38$. Among in-service teachers, there was a significant negative correlation between length of service and overall maths teaching anxiety, $\mathrm{r}(72)=-.27, \mathrm{p}=.02$, and self-directed mathematics teaching anxiety, $\mathrm{r}(72)=-.31, \mathrm{p}<.01$, but not pupil/student-directed mathematics teaching anxiety, $\mathrm{r}(72)=-.11$, $\mathrm{p}=.38$. Means and standard deviations can be seen in Table 1 . 
Table 1. Means (and standard deviations) of maths teaching anxiety (and sub-scales) according to sex and teacher status.

\begin{tabular}{|c|c|c|c|c|}
\hline & & Maths anxiety & $\begin{array}{l}\text { Self-directed } \\
\text { mathematics } \\
\text { teaching anxiety }\end{array}$ & $\begin{array}{l}\text { Pupil/student-directed } \\
\text { teaching mathematics } \\
\text { anxiety }\end{array}$ \\
\hline \multirow[t]{2}{*}{ Sex } & Males & $2.17(0.50)$ & $1.73(0.62)$ & $2.94(0.61)$ \\
\hline & Females & $2.36(0.71)$ & $1.99(0.87)$ & $3.00(0.67)$ \\
\hline \multirow[t]{2}{*}{ Teacher status } & Pre-service & $2.69(0.64)$ & $2.44(0.80)$ & $3.13(0.55)$ \\
\hline & In-service & $2.06(0.58)$ & $1.59(0.66)$ & $2.88(0.55)$ \\
\hline Overall & & $2.33(0.68)$ & $1.94(0.83)$ & $2.99(0.65)$ \\
\hline
\end{tabular}

\section{DISCUSSION and CONCLUSION}

This study used an English version of the Mathematics Teaching Anxiety Scale (Sari, 2014) to assess maths teaching anxiety in pre-service and in-service primary school teachers across the U.K. Results suggested a different factor structure to that reported by Sari (2014), including a reduced number of items. Two factors were labelled self-directed mathematics teaching anxiety (12 items) and pupil/student-directed mathematics teaching anxiety ( 7 items). Respectively, these relate to oneself, including anxiety about one's own maths knowledge, and anxiety directed towards the teaching of others, including worry about one's pupils/students failing assessments or not reaching targets; this second factor is perhaps especially relevant in today's assessment-focused schools.

We observed no significant difference in maths teaching anxiety as a function of sex, which reflects research findings in the field (e.g. Peker \& Halat, 2008; Peker \& Ertekin, 2011). However, we found pre-service teachers to have significantly higher maths teaching anxiety. Further to this, our results showed that length of service as a qualified teacher was inversely related to maths teaching anxiety. Of note though, this relationship was specific to self-directed mathematics teaching anxiety, suggesting that experience may act as a buffer against anxiety concerning one's own teaching ability regarding maths, possibly due to an increase in confidence. This finding may be particularly important given the previous finding that the higher chance of leaving the teaching profession among younger teachers is the result of inexperience rather than being young. Indeed, primary school teachers with less than 2 years' experience are 5\%-10\% more likely to leave the profession than those with 6-10 years' experience (Worth, De Lazzari \& Hillary, 2017). It is worth highlighting that mean maths teaching anxiety scores in the current study were highest on the pupil/student-directed factor, suggesting particular attention should be paid to teachers' anxiety derived from concerns about pupil/student maths understanding and performance. Indeed, items with the greatest factor loading pertained to anxiety about pupils/students not meeting curriculum/school targets and failing assessments.

A notable consideration is that we studied maths teaching anxiety, not general maths anxiety. As such, the results offer several important points to consider. Firstly, it is reassuring that the overall level of maths teaching anxiety was reasonably low; the mean for the sample represented "rarely" "to sometimes" maths teaching anxious. However, it is noteworthy that the sample includes only those individuals who have not withdrawn from training or teaching, thus suggesting a higher level of resilience than those who have; further investigation is needed on a sample of trainees or teachers that have not been retained in the profession. Secondly, our sample was diverse in terms of locations; it is unknown what training participants had received and the extent to which institutional policies play a part in experiencing maths teaching anxiety. Relatedly, pre-service teachers likely varied in the length of training they had received at the 
point of completing the survey. Nevertheless, this is the first study to use a validated measure of maths teaching anxiety with a sample of U.K. pre-service and in-service primary school teachers. The scale is easy to administer and may be useful in identifying at-risk teachers and pre-service teachers; more needs to be done to ensure teachers/trainees are supported and not placed under undue stress with regard to teaching maths. Our findings emphasise the multidimensional nature of maths teaching anxiety and demonstrates the need to look at the needs of pre-service and in-service teachers separately. The data showed that approximately $14 \%$ of respondents scored above "sometimes" in terms of how much maths teaching anxiety they experience. Given the volume of teachers and trainees within primary education this represents a considerable number of individuals in need of additional support and at-risk of leaving the profession due to excess stress in the domain of teaching maths. Whilst care needs to be taken not to over-generalise the findings, this study provides some much needed information concerning the state of maths teaching anxiety within primary education in the U.K., especially in the context of worsening retention rates.

\section{ORCID}

\section{Thomas E. Hunt (io https://orcid.org/0000-0001-5769-1154 \\ Mehmet Hayri Sari iD https://orcid.org/0000-0002-7159-2635}

\section{REFERENCES}

Baloglu, M., \& Kocak, R. (2006). A multivariate investigation of the differences in mathematics anxiety. Personality and Individual Differences, 40, 1325-1335.

Betz, N. E. (1978). Prevalence, distribution, and correlates of maths anxiety in college students. Journal of Counseling Psychology, 25, 441-448.

Bursal, M., \& Paznokas, L. (2006). Mathematics anxiety and preservice elementary preservice teachers' confidence to teach mathematics and science. School Science and Mathematics, $106,173-180$.

Department for Education. (2015). School workforce in England: November 2014. Retrieved from https://www.gov.uk/government/statistics/school-workforce-in-englandnovember-2014

Dreger, R. M., \& Aiken, L. R. (1957). The identification of number anxiety in a college population. Journal of Educational Psychology, 48, 344-351.

Gresham, G. (2018). Preservice to inservice: Does mathematics anxiety change with teaching experience? Journal of Teacher Education, 69, 90-107.

Hadfield, O. D., \& McNeil, K. (1994). The relationship between Myers-Briggs personality type and mathematics anxiety among preservice elementary teachers. Journal of Instructional Psychology, 21, 375-384.

Hadley, K. M., \& Dorward, J. (2011). The relationship among elementary teachers' mathematics anxiety, mathematics instructional practices, and student mathematics achievement. Journal of Curriculum and Instruction, 5(1), 27-44.

Hembree, R. (1990). The nature, effects, and relief of mathematics anxiety. Journal of Research for Mathematics Education, 21, 33-46.

Hunt, T. E., Clark-Carter-D., \& Sheffield, D (2011). The development and part validation of a U.K. scale for mathematics anxiety. Journal of Psychoeducational Assessment, 29, 455466.

Isiksal, M., Curran, J. M., Koc, Y., \& Askun, C. S. (2009). Mathematics anxiety and mathematical self-concept: Considerations in preparing elementary school teachers. Social Behavior and Personality, 37, 631-644.

Jackson, E. (2008). Mathematics in student teachers. Practitioner Research in Higher Education, 2, 36-42. 
Lake, V. E., \& Kelly, L. (2014). Female preservice teachers and mathematics: Anxiety, beliefs, and stereotypes. Journal of Early Childhood Teacher Education, 35, 262-275.

OECD. (2013). PISA 2012 results: Ready to learn: Students' engagement, drive and self-beliefs (Volume III). PISA, OECD Publishing.

Peker, M., \& Ertekin, E. (2011). The relationship between mathematics teaching anxiety and mathematics anxiety. The New Educational Review, 23, 213-226.

Peker, M., \& Halat, E. (2008). The pre-service elementary school teachers' mathematics teaching anxiety and gender, The European Conference on Educational Research, 10-12 September, Goteborg, Sweden.

Plake, B. S., \& Parker, C. S. (1982). The development and validation of a revised version of the mathematics anxiety rating scale. Educational and Psychological Measurement, 42, 551557.

Richardson, F. C., and Suinn, R. M. (1972). The mathematics anxiety rating scale. Journal of Counselling Psychology, 19, 551-554.

Sandman, R. S. (1979). Mathematics anxiety inventory: U ser's manual. Unpublished manuscript, University of Minnesota, Minnesota Research and Evaluation Center, Minneapolis.

Sari, M. H. (2014). Sınıf öğretmenlerine yönelik matematik öğretimi kaygı ölçeği geliştirme [Developing a mathematics teaching anxiety scale for classroom teachers]. Elementary Education Online, 13(4), 1296-1310. Doi: 10.17051/io.2014.11721

Sari, M. H., \& Aksoy, N. C. (2016). Sınıf öğretmenlerinin matematik öğretimi kaygısı ile öğretme stilleri tercihleri arasındaki ilişki [The relationship between mathematics teaching anxiety and teaching style of primary school teachers]. Turkish StudiesInternational Periodical for the Languages, Literature and History of Turkish or Turkic, 11(3), 1953-1968. Doi: 10.7827/TurkishStudies.9322

Tabachnick, B. A., \& Fidell, L. S. (2001). Using multivariate statistics (4th ed). Needham Heights, MA: Allyn and Bacon.

Trujillo, K. M., \& Hadfield, O. D. (1999). Tracing the roots of mathematics anxiety through indepth interviews with preservice elementary teachers. College Student Journal, 33, 219232.

Worth, J. \& De Lazzari, G. (2017). Teacher Retention and Turnover Research. Research Update 1: Teacher Retention by Subject. Slough: NFER.

Worth, J., De Lazzari, G., \& Hillary, J. (2017). Teacher retention and turnover research: interim report. Slough: NFER. 


\section{APPENDICES}

The 19-item Mathematics Teaching Anxiety Scale.

1. The thought of not being able to motivate students to learn maths bothers me.

2. The thought that students find maths too abstract concerns me.

3. The thought that students/pupils will not meet curriculum/school targets in maths worries me.

4. The thought that students/pupils will not pay attention to what I am teaching in maths class worries me.

5. I worry that students/pupils in my maths class will fail their assessments.

6. Differences in students'/pupils' prior knowledge worries me when preparing for maths lessons.

7. I worry that students/pupils will answer maths questions incorrectly.

8. At the end of my maths class, I erase the content on the board so that colleagues can't see.

9. I wait for breaks impatiently when I am in maths classes.

10. I am afraid to go beyond the content of maths textbooks.

11. I avoid talking about mathematics teaching with other teachers outside the classroom.

12. I avoid classroom discussion in case students pose difficult maths questions.

13. I get uneasy knowing that the next lesson is mathematics.

14. I feel nervous when a pre-service/trainee teacher observes my maths teaching.

15. I feel uncomfortable when one of my colleagues comes to my classroom during a maths lesson.

16. I worry that I won't be able to answer a question whilst teaching a maths class.

17. Thinking about how to make use of tools/materials that I don't know how to use in the maths classroom makes me feel anxious.

18. The thought of using concrete tools (e.g. geometry boards, pattern blocks, tangrams, fraction bars) in maths classes worries me.

19. I feel uneasy when students/pupils don't understand mathematical concepts and I have to find/think about alternative methods or strategies to teach them. 